\title{
Genetic differentiation reflects geological history in the Azorean land snail, Leptaxis azorica
}

\author{
P Van Riel ${ }^{1,2}$, K Jordaens ${ }^{2}$, R Verhagen ${ }^{2}$, AM Frias Martins ${ }^{3}$ and T Backeljau ${ }^{1,2}$ \\ ${ }^{1}$ Royal Belgian Institute of Natural Sciences, Malacology Section, Vautierstraat 29, B-1000 Brussels, Belgium; ${ }^{2}$ Department of Biology, \\ Evolutionary Biology Group, University of Antwerp (RUCA), Groenenborgerlaan 171, B-2020 Antwerp, Belgium; ${ }^{3}$ Departamento de \\ Biologia, University of the Azores, Rua da Mãe de Deus, Apartado 1422, P-9502 Ponta Delgada, Azores, Portugal
}

\begin{abstract}
The land snail Leptaxis azorica, endemic on the Azores, was subjected to an electrophoretic (allozymes) and morphometric (genital tract) analysis. Genetic distances suggest the presence of four distinct lineages and are compatible with colonisation proceeding from the eastern, older islands (Santa Maria and São Miguel) to the west (Flores and Corvo). On São Miguel, genetic and morphometric differentiation is concordant with the separate colonisation of two islands that gave rise to the current island 50000 years ago. The maximum time available for differentiation in isolation
\end{abstract}

(0.55 million years) suggests a high rate of allozyme change between the two lineages on São Miguel. This may be related to population isolation and bottlenecks caused by human and volcanic activity on São Miguel in relatively recent times. This is more prominent in the eastern region where populations are also characterised by reduced genetic variation (loss of alleles and heterozygosity) compared to populations elsewhere.

Heredity (2003) 91, 239-247. doi:10.1038/sj.hdy.6800304

Keywords: land snail; allozymes; allopatric speciation; evolutionary rate; genetic variation; Azores islands

\section{Introduction}

Oceanic archipelagoes provide an excellent setting to study the evolutionary forces that drive speciation and diversification. A reliable time frame for geological events, superimposed on patterns of molecular and/or morphological variation, allows inferences about allopatric differentiation, the predominant mode by which new species arise (Emerson, 2002).

The geological history of the Azores is relatively well documented and offers a wide range of ages (0.04-8 My) for the different islands (Morton et al, 1998). Nevertheless, to our knowledge, no published studies have focused on the inter- and intraspecific patterns of genetic variation in relation to the genesis of the Azores (but see Medeiros et al, 2000). The Azores archipelago consists of nine volcanic islands near the Mid-Atlantic Ridge, spanning an area of 530 (latitudes $36^{\circ} 55^{\prime}-39^{\circ} 43^{\prime} \mathrm{N}$ ) by $320 \mathrm{~km}$ (longitudes $25^{\circ}-31^{\circ} 17^{\prime}$ ). There are three groups of islands: a western group (Flores and Corvo), a central group (Terceira, Graciosa, Faial, Pico and São Jorge) and an eastern group (Santa Maria and São Miguel). The largest island, São Miguel, was formed by two separate islands that coexisted for about $0.550 \mathrm{My}$ and that merged about 50000 years ago (Figure 1: Forjaz, 1997).

Land snails represent an important portion of the endemic fauna on the Azores (Backhuys, 1975). Leptaxis azorica (Albers, 1852) is a hygromiid land snail, endemic in the Azores. Two distinct varieties were originally

Correspondence: P Van Riel, Royal Belgian Institute of Natural Sciences, Malacology Section, Vautierstraat 29, B-1000 Brussels, Belgium.

E-mail: patrick.vanriel@naturalsciences.be

Received 5 September 2002; revised 14 March 2003; accepted 15 April 2003 described from the two (oldest) islands of the eastern Azorean group. These varieties are now regarded as subspecies (Backhuys, 1975).

L. a. azorica (Albers, 1852) occurs on São Miguel and the western island group, while there are no records of the species from the central island group. On São Miguel, isolated populations are found scattered over the eastern and western part of the island but not in the intervening, geologically much younger, lower and more urbanised part of the island (Plataforma dos Picos; Figure 1b). On Flores, L. a. azorica is only known from a limited number of localities (Backhuys, 1975), while no individuals of a population from Corvo (AM Frias Martins, unpublished record, 1976) could be found during recent expeditions. The second subspecies, L. a. minor (Backhuys, 1975), is endemic for the easternmost island 'Santa Maria' where it is restricted to the surroundings of Pico Alto.

Using molecular, morphometric and geological data, we aimed at answering the following questions: (1) Can patterns of population differentiation be explained in relation to geological events, colonisation history and/or human disturbance? (2) What is the rate of change and to what extent is differentiation at neutral (allozyme) loci accompanied by morphological changes indicative of reproductive isolation?

\section{Material and methods}

\section{Sampling and sample preparation}

Animals were collected by hand and stored at $-80^{\circ} \mathrm{C}$. A total of 424 specimens were collected from 23 locations across the species range. The 19 populations from São Miguel were assigned to either the eastern or western region (Table 1; Figure 1b). For convenience, the 

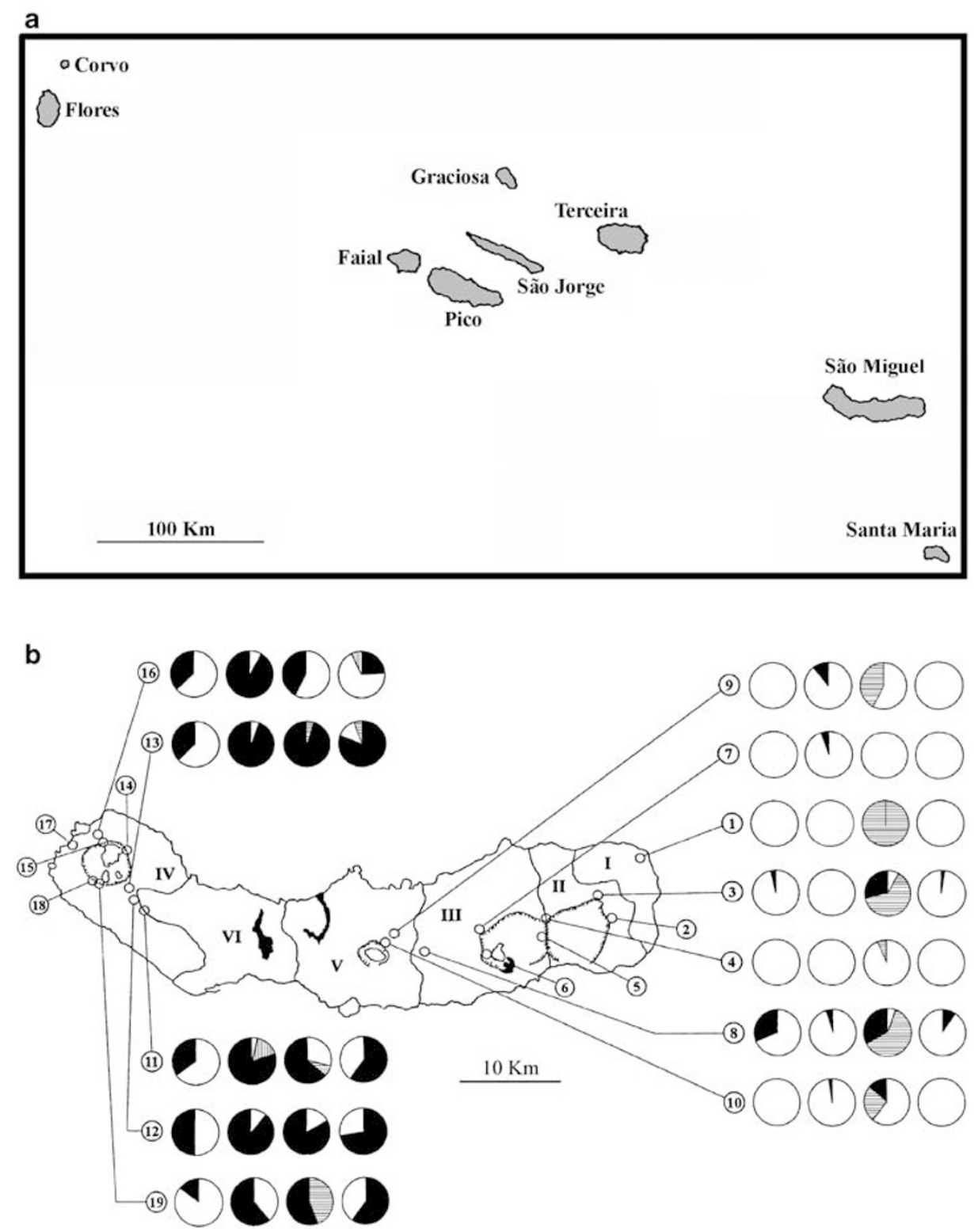

Figure 1 The Azores archipelago (a) and detailed map of the island São Miguel (b) with indication of the sampled populations (see Table 1 for codes) of L. a. azorica, pie charts of allele frequencies for loci that differ most between Lae and Law (EST-1, GPI, LAP and PGM respectively) and the different volcanologic regions (I-VI). Ages: I: 4.2-0.95 My; II: 3.2-0.65 My; III: 0.8 My; IV: 0.55 My; V: 0.29 My; VI: 0.05 My (Forjaz, 1997).

following abbreviations will be used to refer to four 'operational taxonomic units' (OTUs): Lae (L. a. azorica 'east São Miguel'), Law (L. a. azorica 'west São Miguel'), Laf (L. a. azorica 'Flores') and Lam (L.a. minor). The three L. a. azorica OTUs together will be referred to as Laa. All animals were dissected on ice under a stereomicroscope. The digestive gland was removed, weighed and homogenised in a $20 \%$ aqueous sucrose solution $(5 \mu \mathrm{l} / \mathrm{mg}$ tissue). A piece of tissue from the foot muscle was kept at $-80^{\circ} \mathrm{C}$ for future DNA extraction while the remaining soft body parts were stored in $70 \%$ ethanol.

\section{Allozyme electrophoresis}

Vertical polyacrylamide gel electrophoresis (PAGE) was used to screen variation in the following enzyme systems: nonspecific esterases (EST; EC3.1.1.-), aspartate aminotransferase (AAT; EC2.6.1.1), glycerol-3-phosphate dehydrogenase (GPD; EC1.1.1.8), glucose-6-phosphate isomerase (GPI; EC5.3.1.9), 3-hydroxybutyrate dehydrogenase $(\mathrm{HBDH}$; EC1.1.1.30), isocitrate dehydrogenase (IDH; EC1.1.1.42), leucyl aminopeptidase (LAP; EC3.4.11.1), peptidase (PEP; EC3.4.13.18; substrate leuala), phosphoglucomutase (PGM; EC5.4.2.2) and superoxide dismutase (SOD; EC1.15.1.1). Staining recipes were modified after Harris and Hopkinson (1976). The software BIOSYS-1 (Swofford and Selander, 1981) was used to calculate allele frequencies, observed $\left(H_{\mathrm{o}}\right)$ and expected $\left(H_{\mathrm{e}}\right)$ heterozygosities, mean number of alleles $(A)$, percentage polymorphic loci $(P)$, Nei's (1978) unbiased genetic distances $\left(D_{\mathrm{Nei}}\right)$ and to perform a hierarchical analysis of population differentiation by partitioning $F_{\mathrm{ST}}$ into a within-region $\left(F_{\mathrm{SR}}\right)$ and a betweenregion $\left(F_{\mathrm{RT}}\right)$ component $\left(\left(1-F_{\mathrm{ST}}\right)=\left(1-F_{\mathrm{SR}}\right)\left(1-F_{\mathrm{RT}}\right)\right.$; 
Table 1 Sampling localities, sample codes and sample sizes $(N)$ for each population

\begin{tabular}{|c|c|c|c|c|c|}
\hline Species & Island & Location & No. & Code & $\mathrm{N}$ \\
\hline \multirow[t]{21}{*}{ Leptaxis a. azorica } & São Miguel & Nordeste & 1 & Lae1 & 13 \\
\hline & (East) & Serra da Tronqueira & 2 & Lae2 & 5 \\
\hline & & Pico da Vara & 3 & Lae3 & 51 \\
\hline & & Salto do Cavalo & 4 & Lae4 & 79 \\
\hline & & Furnas & 5 & Lae5 & \\
\hline & & Furnas (Lake) & 6 & Lae6 & 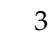 \\
\hline & & Furnas (Golf course) & 7 & Lae7 & 18 \\
\hline & & Monte Escuro I & 8 & Lae8 & 11 \\
\hline & & Monte Escuro II & 9 & Lae9 & 10 \\
\hline & & Lombadas & 10 & Lae10 & 20 \\
\hline & São Miguel & Pico do Carvão & 11 & Law1 & 26 \\
\hline & (West) & Lagoas Empadadas & 12 & Law2 & 10 \\
\hline & & Lagoa do Canário & 13 & Law3 & 30 \\
\hline & & Sete Cidades (Canto Canario) & 14 & Law4 & \\
\hline & & Sete Cidades (Tunnel) & 15 & Law5 & 2 \\
\hline & & Sete Cidades (Cumeeiras) & 16 & Law6 & 50 \\
\hline & & Sete Cidades (Mosteiros) & 17 & Law7 & \\
\hline & & Sete Cidades (Piquete1) & 18 & Law8 & \\
\hline & & Sete Cidades (Piquete2) & 19 & Law9 & 10 \\
\hline & Flores & Terra Nova (Lajedo) & 20 & Laf1 & 20 \\
\hline & & Facho & 21 & Laf2 & 14 \\
\hline \multirow[t]{2}{*}{ Leptaxis a. minor } & Santa Maria & Pico Alto I & 22 & Lam1 & 19 \\
\hline & & Pico Alto II & 23 & Lam2 & 20 \\
\hline
\end{tabular}

Wright, 1978). Population differentiation ( $F_{\mathrm{ST}}$ assuming random or nonrandom mating) and pairwise differences (two-sided test) in allelic richness ( $A$, corrected for sample size), $H_{\mathrm{o}}, H_{\mathrm{e}}, F_{\mathrm{IS}}$ and $F_{\mathrm{ST}}$ between OTUs were tested (null hypothesis of no difference; 1000 permutations) using FSTAT v2.9.3 (Goudet, 1995). The software package GENEPOP v3.1b (Raymond and Rousset, 1995) was used to evaluate ( $\left.F_{\mathrm{IS}}\right)$ deviations from HardyWeinberg equilibrium (HWE), pairwise differences in allele frequencies (exact tests for null hypothesis of respectively no heterozygote deficiency and no differences in allele frequency; default options) and to estimate gene flow (via $F_{\mathrm{ST}}=1 /(1+4 N m)$ (Wright, 1978) and private alleles (Slatkin, 1985)). Correlations between genetic and morphometric data were tested for significance using the Mantel test (1000 permutations; goodness-of-fit statistic $=$ stress 2$)$ implemented by NTSYS v1.8 (Rohlf, 1993). For each tested parameter, the sequential Bonferroni technique was used to reduce the chance of making type I errors (Rice, 1989).

Genetic distances were evaluated by nonmetric multidimensional scaling (NMDS), combined with a minimum spanning tree (MST) as implemented by NTSYS v1.8 (Rohlf, 1993).

Given the small sample sizes of some populations, all analyses were repeated using both populations from Laf and Lam, but only the largest populations of Lae (nos. 3, $4,7)$ and Law (nos. 11, 13, 16).

\section{Morphometry of shell and genital tract}

A Wild-Heerbrugg micrometer attached to a stereomicroscope (accuracy: 0.01-1 mm, depending on the magnification) was used to take 16 measurements of the genital tract (Figure 2). For each adult individual we measured the following: length and width (at the vas deferens) of the flagellum (LF and WF), length (between the penis retractor and the vas deferens) and width (at the vas deferens) of the epiphallus (LE and WE), length

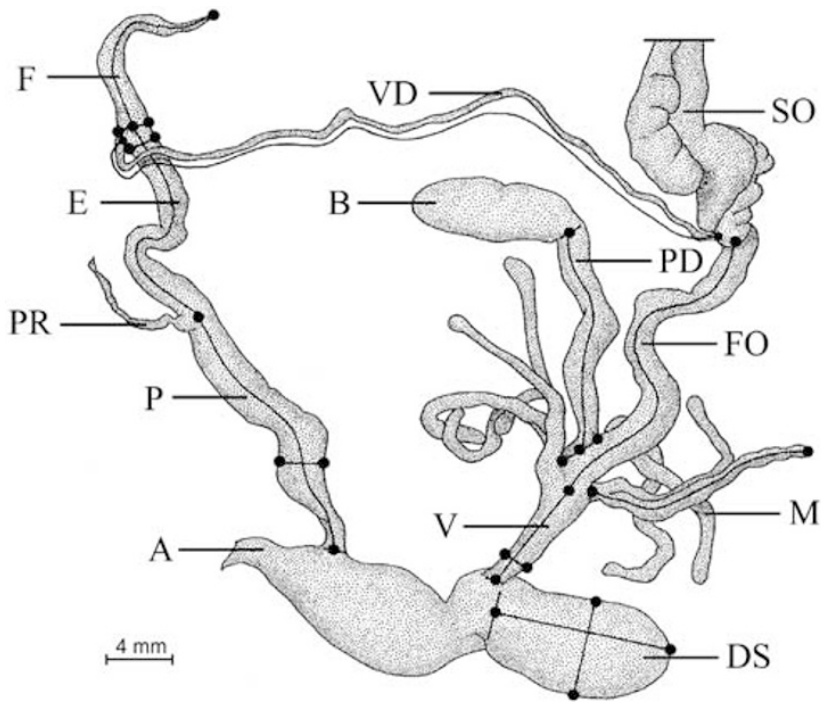

Figure 2 Camera lucida drawing of the genital tract of L. azorica showing the landmarks of the characters measured (see also text). Abbreviations: A: genital atrium; B: bursa copulatrix; DS: dart sac; E: epiphallus; F: flagellum; FO: free oviduct; $\mathrm{M}$ : mucus gland; $\mathrm{P}$ : penis; PD: pedunculus; PR: penis retractor; SO: spermoviduct; V: vagina; VD: vas deferens. Scale: $1 \mathrm{~mm}$.

(between atrium and penis retractor) and width (at the enlargement) of the penis (LP and WP), length and width of the dart sac (LDS and WDS), length of the free oviduct (LFO; between the dart sac and the spermoviduct), length (between dart sac and mucus glands) and width of the vagina (LV and $\mathrm{WV}$ ), length of the largest diverticulum of the mucus gland (MM), length (between oviduct and bursa copulatrix) of the pedunculus (LPD) and length and width (at the epiphallus/flagellum) of the vas deferens (LVD and WVD). In order to approximate normality and linearity of relations, all variables were $\log 10$ transformed. In snails, overall body size is 


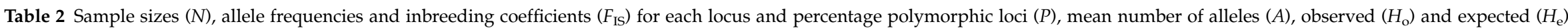
heterozygosities and $F_{\mathrm{IS}}$ for each population

\begin{tabular}{|c|c|c|c|c|c|c|c|c|c|c|c|c|c|c|c|c|c|}
\hline & Lae1 & Lae3 & Lae4 & Lae7 & Lae8 & Lae9 & Lae10 & Law1 & Law2 & Law3 & Law6 & Law8 & Law9 & Laf1 & Laf2 & Lam1 & Lam2 \\
\hline$A A T$ & 9 & 38 & 61 & 18 & 11 & 7 & 13 & 23 & 9 & 29 & 48 & 3 & 10 & 19 & 11 & 19 & 19 \\
\hline A & - & - & - & - & - & - & - & - & 0.056 & - & - & - & - & - & - & - & - \\
\hline B & - & - & - & - & - & - & - & - & - & - & - & - & - & - & - & 1.000 & 0.974 \\
\hline C & 1.000 & 0.987 & 0.975 & 1.000 & 1.000 & 1.000 & 1.000 & 0.957 & 0.833 & 0.638 & 1.000 & 1.000 & 1.000 & 1.000 & 1.000 & - & 0.026 \\
\hline $\mathrm{D}$ & - & 0.013 & 0.025 & - & - & - & - & 0.043 & 0.111 & 0.362 & - & - & - & - & - & - & - \\
\hline$F_{\text {IS }}$ & - & 0.000 & -0.017 & - & - & - & - & -0.023 & -0.091 & 0.047 & - & - & - & - & - & - & 0.000 \\
\hline EST-1 & 13 & 39 & 70 & 18 & 11 & 9 & 19 & 24 & 8 & 29 & 43 & 6 & 10 & 18 & 14 & 16 & 18 \\
\hline A & - & - & - & - & - & - & - & - & - & - & - & - & - & - & - & 0.063 & - \\
\hline B & - & - & - & - & - & - & - & - & - & - & - & - & - & - & - & 0.063 & 0.056 \\
\hline C & - & - & - & - & - & - & - & - & - & - & - & - & - & - & - & - & 0.083 \\
\hline D & 1.000 & 0.962 & 1.000 & 1.000 & 0.682 & 1.000 & 1.000 & 0.646 & 0.500 & 0.621 & 0.628 & 0.917 & 0.850 & 0.083 & 0.714 & 0.625 & 0.694 \\
\hline E & - & - & - & - & - & - & - & - & - & - & - & - & - & - & - & - & 0.028 \\
\hline $\mathrm{F}$ & - & 0.038 & - & - & 0.318 & - & - & 0.354 & 0.500 & 0.379 & 0.372 & 0.083 & 0.150 & 0.917 & 0.286 & 0.219 & 0.139 \\
\hline G & - & - & - & - & - & - & - & - & - & - & - & - & - & - & - & 0.031 & - \\
\hline$F_{\text {IS }}$ & - & -0.027 & - & - & 0.000 & - & - & 0.201 & -0.448 & 0.429 & 0.016 & 1.000 & -0.125 & 0.653 & -0.368 & $0.786^{*}$ & 0.003 \\
\hline EST-2 & 13 & 39 & 70 & 18 & 11 & 9 & 19 & 25 & 8 & 29 & 43 & 5 & 10 & 19 & 14 & 16 & 18 \\
\hline A & - & - & - & - & - & - & - & - & - & - & - & - & - & - & - & 0.031 & - \\
\hline B & - & 0.026 & 0.007 & - & - & - & - & - & - & - & 0.198 & - & - & - & - & 0.563 & 0.472 \\
\hline C & 1.000 & 0.974 & 0.979 & 1.000 & 1.000 & 1.000 & 0.947 & 1.000 & 1.000 & 1.000 & 0.802 & 0.700 & 1.000 & 0.395 & 0.536 & 0.406 & 0.528 \\
\hline D & - & - & 0.014 & - & - & - & 0.053 & - & - & - & - & - & - & - & - & - & - \\
\hline E & - & - & - & - & - & - & - & - & - & - & - & 0.300 & - & 0.605 & 0.464 & - & - \\
\hline$F_{\text {IS }}$ & - & -0.013 & $0.665^{*}$ & - & - & - & 1.000 & - & - & - & 0.059 & 0.600 & - & 0.254 & 0.594 & 0.186 & 0.025 \\
\hline GPD & 10 & 23 & 45 & 18 & 10 & 6 & 16 & 23 & 7 & 27 & 20 & 0 & 7 & 19 & 14 & 8 & 10 \\
\hline A & 0.250 & - & 0.044 & - & 0.250 & - & 0.250 & 0.109 & - & 0.111 & 0.025 & - & - & - & - & - & - \\
\hline B & 0.750 & 1.000 & 0.956 & 1.000 & 0.750 & 1.000 & 0.750 & 0.891 & 1.000 & 0.889 & 0.975 & - & 1.000 & 1.000 & 1.000 & 1.000 & 1.000 \\
\hline$F_{\text {IS }}$ & 0.250 & - & -0.035 & - & 0.250 & - & 0.032 & 0.784 & - & 0.636 & 0.000 & - & - & - & - & - & - \\
\hline GPI & 13 & 36 & 72 & 18 & 10 & 9 & 19 & 25 & 9 & 29 & 43 & 5 & 9 & 15 & 14 & 18 & 17 \\
\hline A & - & - & - & - & - & - & - & - & - & - & - & - & - & 0.067 & - & 0.026 & - \\
\hline B & 1.000 & 1.000 & 1.000 & 0.944 & 0.950 & 0.889 & 0.974 & 0.040 & 0.111 & 0.052 & 0.081 & 0.300 & 0.389 & 0.833 & 1.000 & 0.895 & 0.794 \\
\hline C & - & - & - & - & - & - & - & 0.160 & - & - & - & - & - & - & - & - & - \\
\hline D & - & - & - & 0.056 & 0.050 & 0.111 & 0.026 & 0.800 & 0.889 & 0.948 & 0.919 & 0.700 & 0.611 & 0.100 & - & - & - \\
\hline $\mathrm{E}$ & - & - & - & - & - & - & - & - & - & - & - & - & - & - & - & 0.079 & 0.206 \\
\hline$F_{\text {IS }}$ & - & - & - & 1.000 & - & -0.067 & 0.000 & 0.768 & -0.067 & 0.659 & -0.077 & 0.600 & 0.789 & -0.111 & - & -0.067 & 0.484 \\
\hline
\end{tabular}




\begin{tabular}{|c|c|c|c|c|c|c|c|c|c|c|c|c|c|c|c|c|c|c|}
\hline$H B D H$ & 7 & 38 & 33 & 18 & 10 & 7 & 6 & 22 & 6 & 29 & 21 & 0 & 8 & 15 & 7 & 2 & 10 & \\
\hline A & 0.286 & 0.105 & 0.219 & - & 0.200 & - & 0.167 & 0.023 & 0.167 & 0.017 & 0.095 & - & 0.563 & - & - & - & - & \\
\hline $\mathrm{B}$ & 0.714 & 0.895 & 0.781 & 1.000 & 0.800 & 1.000 & 0.833 & 0.977 & 0.833 & 0.983 & 0.905 & - & 0.438 & 1.000 & 1.000 & 1.000 & 0.350 & \\
\hline C & - & - & - & - & ----- & - & - & - & - & - & - & - & - & - & - & - & 0.650 & \\
\hline$F_{\mathrm{IS}}$ & -0.333 & 0.175 & 0.464 & - & 0.419 & - & 1.000 & 0.000 & -0.111 & 0.000 & -0.081 & - & 0.774 & - & - & - & 0.800 & \\
\hline IDH & 10 & 38 & 61 & 18 & 9 & 8 & 19 & 23 & 9 & 29 & 32 & 2 & 10 & 17 & 3 & 14 & 13 & \\
\hline A & - & - & - & - & - & - & - & 0.130 & - & - & 0.031 & - & - & - & - & - & - & \\
\hline B & - & 0.105 & 0.057 & 0.111 & 0.111 & - & 0.263 & - & - & 0.052 & - & - & - & 0.118 & - & - & - & \\
\hline C & 1.000 & 0.895 & 0.943 & 0.889 & 0.889 & 1.000 & 0.737 & 0.870 & 1.000 & 0.948 & 0.641 & 1.000 & 1.000 & 0.676 & 1.000 & 0.893 & 1.000 & \\
\hline $\mathrm{D}$ & - & - & - & - & - & - & - & - & - & - & - & - & - & - & - & 0.036 & - & \\
\hline $\mathrm{E}$ & - & - & - & - & - & - & - & - & - & - & - & - & - & 0.206 & - & - & - & \\
\hline $\mathrm{F}$ & - & - & - & - & - & - & - & - & - & - & 0.328 & - & - & - & - & 0.071 & - & \\
\hline$F_{\text {IS }}$ & - & -0.104 & 0.251 & 1.000 & -0.067 & - & -0.059 & $1.000^{*}$ & - & 0.659 & 0.428 & - & - & 0.420 & - & -0.054 & - & \\
\hline$L A P$ & 12 & 26 & 56 & 18 & 9 & 7 & 14 & 22 & 6 & 21 & 21 & 3 & 9 & 15 & 1 & 3 & 11 & \\
\hline A & - & - & - & - & - & - & - & - & - & - & - & - & - & 1.000 & 1.000 & - & - & \\
\hline B & - & 0.077 & 0.955 & 1.000 & 0.056 & 0.571 & 0.607 & 0.295 & 0.167 & - & 0.571 & - & - & - & - & - & - & \\
\hline C & 1.000 & 0.635 & 0.045 & - & 0.611 & 0.429 & 0.250 & 0.068 & - & 0.048 & - & - & 0.444 & - & - & 1.000 & 0.818 & \\
\hline $\mathrm{D}$ & - & 0.288 & - & - & 0.333 & - & 0.143 & 0.636 & 0.833 & 0.952 & 0.429 & 1.000 & 0.556 & - & - & - & 0.182 & \\
\hline$F_{\mathrm{IS}}$ & - & $0.633^{*}$ & 0.380 & - & 0.805 & 1.000 & $0.879 *$ & 0.476 & 1.000 & 1.000 & 0.052 & - & 0.590 & - & - & - & 0.429 & \\
\hline PEP-1 & 13 & 38 & 71 & 18 & 11 & 9 & 18 & 25 & 8 & 29 & 50 & 6 & 10 & 19 & 12 & 18 & 20 & \\
\hline A & - & - & - & - & - & - & - & - & - & - & - & - & - & - & - & 0.056 & - & \\
\hline B & 1.000 & 1.000 & 1.000 & 1.000 & 1.000 & 1.000 & 1.000 & 1.000 & 1.000 & 1.000 & 1.000 & 1.000 & 1.000 & 1.000 & 1.000 & 0.611 & 0.700 & \\
\hline C & - & - & - & - & - & - & - & - & - & - & - & - & - & - & - & 0.333 & 0.300 & \\
\hline$F_{\text {IS }}$ & - & - & - & - & - & - & - & - & - & - & - & - & - & - & - & $1.000^{*}$ & $1.000^{*}$ & \\
\hline PGM & 13 & 38 & 59 & 18 & 11 & 9 & 18 & 25 & 9 & 29 & 21 & 6 & 10 & 19 & 14 & 8 & 13 & \\
\hline A & - & 0.026 & - & - & 0.091 & - & - & 0.600 & 0.722 & 0.759 & 0.238 & - & 0.600 & 0.132 & - & - & - & \\
\hline B & - & - & - & - & - & - & - & - & - & - & - & - & - & - & - & - & 0.038 & \\
\hline C & 1.000 & 0.974 & 1.000 & 1.000 & 0.909 & 1.000 & 1.000 & 0.400 & 0.278 & 0.138 & 0.690 & 1.000 & 0.400 & 0.868 & 1.000 & 1.000 & 0.962 & \\
\hline D & - & - & - & - & - & - & - & - & - & 0.103 & - & - & - & - & - & - & - & 훟 \\
\hline E & - & - & - & - & - & - & - & - & - & - & 0.071 & - & - & - & - & - & - & 焉 \\
\hline$F_{\mathrm{IS}}$ & - & -0.014 & - & - & -0.053 & - & - & 0.020 & -0.333 & 0.317 & 0.300 & - & -0.200 & -0.125 & - & - & 0.000 & 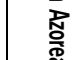 \\
\hline$P$ & 16.67 & 58.33 & 50 & 16.67 & 58.33 & 16.67 & 50 & 66.67 & 50 & 66.67 & 66.67 & 40 & 41.67 & 41.67 & 16.67 & 41.67 & 66.67 & 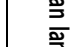 \\
\hline$A$ & $\begin{array}{l}1.17 \\
(.11)\end{array}$ & $\begin{array}{l}1.67 \\
(.19)\end{array}$ & $\begin{array}{l}1.58 \\
(.19)\end{array}$ & $\begin{array}{l}1.17 \\
(.11)\end{array}$ & $\begin{array}{l}1.67 \\
(.19)\end{array}$ & $\begin{array}{l}1.17 \\
(.11)\end{array}$ & $\begin{array}{l}1.58 \\
(.19)\end{array}$ & $\begin{array}{l}1.83 \\
(.21)\end{array}$ & $\begin{array}{l}1.58 \\
(.19)\end{array}$ & $\begin{array}{c}1.75 \\
(.18)\end{array}$ & $\begin{array}{c}1.83 \\
(.21)\end{array}$ & $\begin{array}{l}1.40 \\
(.16)\end{array}$ & $\begin{array}{l}1.42 \\
(.15)\end{array}$ & $\begin{array}{l}1.58 \\
(.23)\end{array}$ & $\begin{array}{l}1.17 \\
(.11)\end{array}$ & $\begin{array}{l}1.92 \\
(.38)\end{array}$ & $\begin{array}{l}1.92 \\
(.31)\end{array}$ & $\begin{array}{l}\text { 言 } \\
\text { 产 }\end{array}$ \\
\hline$H_{\mathrm{o}}$ & 0.073 & 0.064 & 0.040 & 0.000 & 0.131 & 0.019 & 0.077 & 0.115 & 0.183 & 0.098 & 0.188 & 0.057 & 0.113 & 0.110 & 0.065 & 0.082 & 0.132 & \\
\hline & $(.052)$ & $(.023)$ & $(.017)$ & $(.000)$ & $(.042)$ & (.019) & $(.044)$ & $(.048)$ & $(.075)$ & $(.043)$ & $(.052)$ & $(.029)$ & $(.053)$ & $(.045)$ & $(.049)$ & $(.040)$ & $(.053)$ & \\
\hline$H_{\mathrm{e}}$ & $\begin{array}{l}0.070 \\
(.047)\end{array}$ & $\begin{array}{c}0.092 \\
(.044)\end{array}$ & $\begin{array}{l}0.060 \\
(.029)\end{array}$ & $\begin{array}{c}0.026 \\
(.018)\end{array}$ & $\begin{array}{l}0.184 \\
(.058)\end{array}$ & $\begin{array}{l}0.061 \\
(.046)\end{array}$ & $\begin{array}{l}0.151 \\
(.059)\end{array}$ & $\begin{array}{c}0.198 \\
(.060)\end{array}$ & $\begin{array}{l}0.173 \\
(.057)\end{array}$ & $\begin{array}{l}0.157 \\
(.054)\end{array}$ & $\begin{array}{l}0.220 \\
(.063)\end{array}$ & $\begin{array}{c}0.163 \\
(.073)\end{array}$ & $\begin{array}{c}0.194 \\
(.072)\end{array}$ & $\begin{array}{l}0.140 \\
(.057)\end{array}$ & $\begin{array}{c}0.078 \\
(.053)\end{array}$ & $\begin{array}{c}0.166 \\
(.067)\end{array}$ & $\begin{array}{c}0.225 \\
(.064)\end{array}$ & \\
\hline$F_{\text {IS }}$ & -0.052 & 0.308 & 0.342 & 1.000 & 0.302 & 0.715 & 0.506 & 0.422 & -0.054 & 0.378 & 0.144 & 0.691 & 0.432 & 0.225 & 0.169 & 0.513 & 0.422 & \\
\hline
\end{tabular}


influenced by environmental factors (see eg Cameron and Carter, 1979), and the size of the genital organs may vary with reproductive state and season (Jordaens et al, 2002 and references therein). Therefore, the influence of body size and possible allometric relation were removed by regressing (model II regression) all log 10 transformed measurements against $\log 10$ LDS. LDS was the least elastic length variable and was thus expected to have the smallest measurement error. The size-free residuals were analysed in a principal component analysis (PCA). The discriminating power of the PCs was then evaluated by using the individual scores of the PCs in a discriminant analysis (DA). The total sample size $(N)$ for the analyses was 230 with $N=119,65,20$ and 26 for Lae, Law, Laf and Lam, respectively. All computations were done with the software package STATISTICA v5.1 (StatSoft Inc., 1995).

\section{Results}

\section{Allozymes}

A total of 12 putative loci could be scored unambiguously. All parameter values are based on all populations with $N>5$. These data are highly congruent with the results using only the largest populations (see above). Sample sizes $(N)$, allele frequencies, values for $H_{\mathrm{o}}, H_{\mathrm{e}}, P$, $A, F_{\mathrm{IS}}, F_{\mathrm{ST}}, N m$, the proportion of unique alleles $(U)$ and deviations from HWE (each locus in each locality) are summarised in Tables 2 and 3. A significant difference in $H_{\mathrm{e}}$ could be detected (after Bonferroni correction) between Lae and $\operatorname{Lam}(P=0.005)$. Values for $F_{\mathrm{IS}}$ and $F_{\mathrm{ST}}$ were significantly different from zero $(P=0.001)$ in all OTUs (over all loci). After Bonferroni correction, no consistent significant deviations from HWE could be detected (tests per locus and population) at any particular locus or population (see Table 2). Except in Laf and Lam (small sample size), $F_{\mathrm{ST}}$ also differed significantly from zero $(P=0.001)$ when tested under the assumption of nonrandom mating. All loci besides $S O D$, PEP-1 (both nearly monomorphic), PEP-2 and GPD (fixed in Laa and Lam, respectively) showed significant differentiation of allele frequencies between populations, for the most part between populations from different OTUs. In agreement with this, mean values for Nei's (1978) unbiased genetic distances are much smaller

Table 3 Mean values for each OTU of percentage of polymorphic loci $(P)$, mean number of alleles $(A)$, percentage unique alleles $(U$; calculated within each OTU) and their mean frequency $(p)$, observed $\left(H_{\mathrm{o}}\right)$ and expected $\left(H_{\mathrm{e}}\right)$ heterozygosities, inbreeding coefficients $\left(F_{\mathrm{IS}}\right)$, fixation indices $\left(F_{\mathrm{ST}}\right)$ and mean number of migrants per generation $(\mathrm{Nm})$ via $F_{\mathrm{ST}}$ and private alleles (not present in Lae)

\begin{tabular}{lcccc}
\hline & Lae & Law & Laf & Lam \\
\hline$P$ & $38 \%$ & $58 \%$ & $29 \%$ & $54 \%$ \\
$A$ & 1.43 & 1.68 & 1.37 & 1.92 \\
$U$ (mean $p)$ & $4 \%(0.033)$ & $21 \%(0.119)$ & $16 \%(0.655)$ & $42 \%(0.238)$ \\
$H_{\mathrm{o}}$ & 0.058 & 0.139 & 0.087 & 0.107 \\
$H_{\mathrm{e}}$ & 0.092 & 0.188 & 0.109 & 0.195 \\
$F_{\mathrm{IS}}$ & 0.446 & 0.264 & 0.197 & 0.467 \\
$F_{\mathrm{ST}}$ & 0.307 & 0.152 & 0.263 & 0.014 \\
$N m$ (F $\left.F_{\mathrm{ST}}\right)$ & 0.56 & 1.39 & 0.70 & 17.61 \\
$N m$ (priv) & - & 0.45 & 0.51 & 0.80 \\
\hline
\end{tabular}

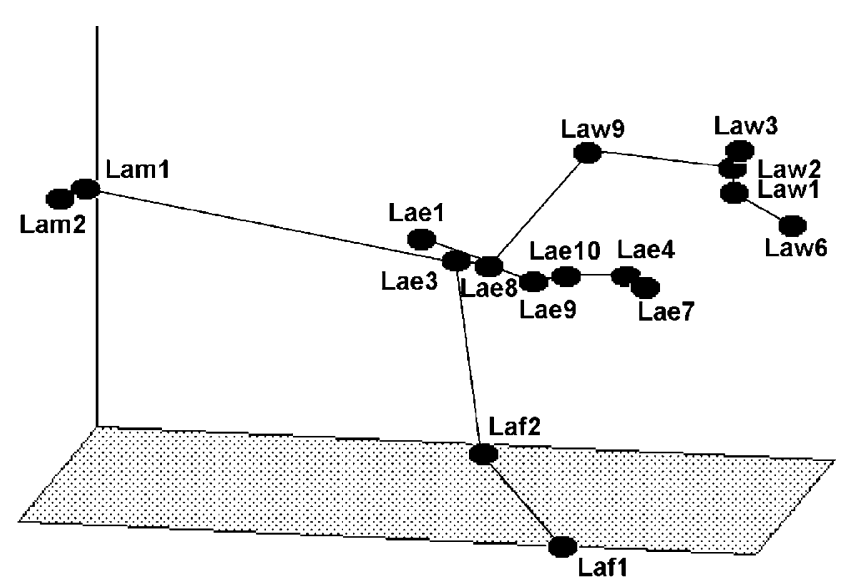

Figure 3 Plot of Nei's (1978) unbiased genetic distance among all populations of L. azorica $(N>5)$ via NMDS (three dimensions; stress $=0.073$ ) with a superimposed MST. Population codes are given in Table 1.

within (mean $D_{\mathrm{Nei}}$ : 0.036-0.047), than between OTUs $\left(D_{\mathrm{Nei}}: 0.163-0.380\right)$. Genetic distances between all populations are represented graphically in Figure 3. On a total of 47 alleles over all loci, 23 alleles $(49 \%)$ were shared among all OTUs with Lam accounting for the major part (percentages calculated within each OTU) of unique alleles ( $42 \%$; high frequency), followed by Law (21\%; low frequency), Laf (16\%; high frequency) and Lae (4\%; low frequency). Remarkable is the high frequency of a private allele ' $C$ ' for locus GPI in population Law1, the easternmost population of Law. The hierarchical F-statistics (Wright, 1978) confirmed the strong differentiation between Lae and Law $\left(F_{\mathrm{ST}}=0.388\right)$ on São Miguel. The between-region variance component was higher $(59 \%$; mean $\left.F_{\mathrm{RT}}=0.228\right)$ compared to the within-region component $\left(41 \%\right.$; mean $\left.F_{\mathrm{SR}}=0.208\right)$. Although statistically not significant between any OTUs, $F_{\mathrm{ST}}$ is markedly higher among populations of Lae (mean $F_{\mathrm{ST}}=0.307$ ) and Laf (mean $F_{\mathrm{ST}}=0.263$ ) than among populations of Law (mean $F_{\mathrm{ST}}=0.152$ ) and Lam (mean $F_{\mathrm{ST}}=0.014$ ). The lower values for $F_{\mathrm{ST}}$ in Lam and Law result in $N m>1$ (17.6 and 1.4, respectively), but this is not confirmed by estimates via private alleles.

\section{Morphometry}

The PCA of the size-free residuals of the 15 measurements of the genital tract yielded two PCs with eigenvalues $>1$ and a third $\mathrm{PC}$ with an eigenvalue $\approx 1$, together explaining $76 \%$ of the observed variation (Table 4). The first PC accounted for $44 \%$ of the total variation and represents the shape of the male parts (spermatophore producing organs; LE, LP, LVD) and the pedunculus (spermatophore receiving organ; LPD). PC2 explained $26 \%$ of the total variation and was strongly negatively correlated with some measurements, mainly those defining the shape in parts of the genital tract that are not directly involved with the transfer of the spermatophore (MM, LFO and WDS). PC3 explained $6 \%$ of the total variation and was strongly positively correlated with LV. Using a DA, $70 \%$ of the individuals could be classified correctly into the appropriate OTU (Table 5). However, the majority of individuals of Law were erroneously classified with Lae (43\%), whereas 
Table 4 Eigenvalues, percentage explained variation and factor loadings for the first three principal components of a PCA on 15 measurements (size-free residuals) of the genital tract

\begin{tabular}{lccc}
\hline Variable & PC1 & PC2 & PC3 \\
\hline MM & -0.201 & -0.765 & -0.260 \\
LF & -0.559 & -0.641 & -0.179 \\
LE & -0.663 & -0.385 & -0.035 \\
LP & -0.667 & -0.543 & 0.185 \\
LPD & -0.712 & -0.283 & -0.055 \\
LFO & -0.484 & -0.710 & -0.002 \\
LV & 0.069 & -0.397 & 0.890 \\
LVD & -0.799 & -0.507 & -0.029 \\
WF & 0.808 & -0.376 & -0.057 \\
WE & 0.799 & -0.416 & -0.118 \\
WP & 0.724 & -0.522 & -0.002 \\
WPD & 0.770 & -0.433 & -0.043 \\
WDS & 0.478 & -0.718 & 0.000 \\
WV & 0.789 & -0.310 & -0.021 \\
WVD & 0.888 & -0.131 & 0.016 \\
Eigenvalue & 6.68 & 3.84 & 0.95 \\
\% variation & 44 & 26 & 6 \\
\hline
\end{tabular}

Table 5 Classification table of a discriminant analysis based on individual scores for the first three principal components from the PCA

\begin{tabular}{lrrccc}
\hline OTU & Lae & Law & Laf & Lam & \% correct \\
\hline Lae $(N=119)$ & 101 & 18 & 0 & 0 & 85 \\
Law $(N=65)$ & 28 & 33 & 1 & 3 & 51 \\
Laf $(N=20)$ & 1 & 6 & 5 & 8 & 25 \\
Lam $(N=26)$ & 0 & 2 & 2 & 22 & 85 \\
Total & 130 & 59 & 8 & 33 & 70 \\
\hline
\end{tabular}

many individuals of Laf were classified as Law (30\%) or Lam (40\%).

\section{Discussion}

Our study represents an example of (vicariant) speciation in close concordance with the geological history of the Azorean islands. Most genetic variation present in $L$. azorica is contained in four OTUs (Lam, Lae, Law and Laf) that coincide with (former) islands. The genetic distances between the four OTUs are typical for congeneric (allopatric) species in several families of pulmonate land snails (eg Boato, 1988; Chiba, 1993; Johnson et al, 2000). Nevertheless, genetic distances do not provide a yardstick for discriminating between taxonomic levels, and considerable differentiation between conspecific populations is not uncommon in land snails (eg Selander and Kaufman, 1975; Ochman et al, 1987).

Additional evidence for (ongoing) speciation is the reproductive isolation that may be inferred from the morphometric differences in the genital tract. Although even large morphometric differences do not necessarily lead to reproductive isolation (eg Johnson et al, 1993), it has been argued that small length differences between the spermatophore producing and receiving parts of the sexual organs of copulating pairs may cause (partial) reproductive isolation (Madec and Guiller, 1993; Jor- daens et al, 2002). Although the former two islands that constitute São Miguel have been connected for 50000 years, homogenisation or more extensive mixing of the gene pools in the two regions has not occurred (Figure 1b; Table 2). The only indication for gene flow between Lae and Law comes from the observation of a private allele at high frequency in population Law1 (locus GPI, allele C), which could be tentatively interpreted as a 'hybrizyme' (Figure 1b; Table 2). An increasing frequency of rare electromorphic variants towards the contact zone between hybridising taxa is a commonly observed phenomenon (see eg Woodruff, 1989) but needs further investigation for L. azorica on São Miguel. Although occasional contact may be possible, our results show that there is essentially no gene flow $(N m<1)$ going on between the populations of Laa, certainly not between Lae and Law on the island São Miguel. This could be expected, given the limited dispersal capabilities of land snails (eg Schilthuizen and Lombaerts, 1994) and the high degree of habitat fragmentation in eastern São Miguel (Mitchell-Thomé, 1976). The younger region between East and West São Miguel, that is, the Plataforma dos Picos (Figure 1b), is the most urbanised part of the island and it may also lack suitable habitat because of its lower elevation (Forjaz, 1997) and its different microecological conditions. The populations sampled in the western region (Law) are all located in the green belt around the Caldeira of Sete Cidades (Figure 1b), which could explain the lower values for $F_{\mathrm{ST}}$ and concomitant higher levels of gene flow $(N m>1)$. On the island Santa Maria, the lack of differentiation (and gene flow estimates $>>1$ ) between the two putative populations of Lam, probably indicates that they represent one panmictic unit. The high value for $F_{\mathrm{IS}}$ in Lam, also after increasing the sample size by pooling both populations, could be explained by the fact that these animals are most commonly found on the invasive, exotic plant, Hedychium gardneranum. Regularly, large areas are cleared in order to control the spread of this plant (Van Riel et al, 2000) probably provoking the loss of numerous individuals and thereby increasing the oppurtunity of genetic drift. However, estimates of variability and gene flow for Lam, and also Laf, must be seen in perspective, given the small sample sizes for these OTUs.

Rates of allozyme change $\left(D_{\mathrm{Nei}} /\right.$ time) calibrated on the upper time limits ( 2 and $4 \mathrm{My}$, respectively) for the split between Laa on São Miguel/Flores and Laa/Lam $(0.101 \pm 0.035$ and $0.072 \pm 0.022$ per My, respectively) are similar to that calculated for Partula from the Society Islands $(0.126 \pm 0.062$ per My; Johnson et al, 2000). However, given the maximum time of $0.55 \mathrm{My}$ for differentiation between Lae and Law, the rate of allozyme change $(0.325 \pm 0.107$ per My) by far exceeds the previous values. Of course, a considerable amount of additional error is introduced in the rate calculations by the fact that colonisation of an island does not necessarily coincide with its emergence. However, the absence of L. a. azorica on the central Azorean islands is less difficult to explain if we assume that colonisation of the western islands took place before the former arose above sea level. Furthermore, graphs based on genetic distances are compatible with colonisation that proceeded from the older, easternmost islands further westward (Figures 1 and 3). Most authors agree that Flores (2 My) 
is older than most of the islands of the central group (range: $\pm 0.04-1 \mathrm{My}$, except Terceira: $\pm 2-4 \mathrm{My}$ ) (Morton et al, 1998). Higher evolutionary rates and/or divergent selection have been invoked as possible mechanisms to bring about extreme intraspecific genetic divergence in, for example, mitochondrial DNA sequences of some helicid land snails (eg Hayashi and Chiba, 2000; Thomaz et al, 1996). In general, a higher susceptibility for genetic drift and natural selection in land snails can be related to their generally patchy distributions caused by their limited dispersal ability and/or dependence on specific (micro-) ecological conditions (eg Boato, 1988; Schilthuizen and Lombaerts, 1994).

Nevertheless, while there is no a priori reason to assume rate heterogeneity and/or the existence of coadapted gene complexes (eg Davison and Clarke, 2000) within Laa, our results show some evidence for stronger effects of genetic drift in the populations of Lae (and Laf) which are characterised by lower values for $A$ and $H$ (see eg Leberg, 1992). Fast differentiation and loss of genetic variability is often attributed to genetic drift involved with the (re)colonisation of new areas, especially in organisms with limited dispersal capabilities (see eg Ibrahim et al, 1996). Population isolation and bottlenecks may also be related to the destruction of suitable habitat by volcanic and/or human activities. São Miguel is most densely populated and has suffered most from volcanic activity in relatively recent times (1563, 1630, 1652), especially the eastern region (MitchellThomé, 1976; Morton et al, 1998). The devastating effects of human activities on land snail communities (eg Goodfriend et al, 1994; Van Riel et al, 2000) undoubtedly have their repercussions on population genetic diversity (eg Leberg, 1992; Ibrahim et al, 1996). Recently, many studies addressed evolution on (volcanic) oceanic islands using a molecular phylogenetic approach (Emerson, 2002). As geological and biological data accumulate, patterns of variation within single islands are more and more related to vicariant events caused by volcanic activity in relatively recent times. Isolation and eradication of populations by lava flows have been invoked to explain phylogeographic structure in, for example, anoles (Malhotra and Thorpe, 2000), beetles (Emerson et al, 1999) and land snails (Shimizu and Ueshima, 2000). The fusion of two or more islands can explain the existence of different DNA lineages on, for example, the Canarian island Tenerife (Juan et al, 2000). On São Miguel, additional evidence for such a scenario comes from the preliminary results of a genetic analysis of another endemic land gastropod, that is, the slug Plutonia atlantica (Medeiros et al, 2000). Currently, mitochondrial and nuclear DNA sequences of L. azorica are being analysed in order to test the hypotheses with respect to colonisation and diversification, which have been outlined in this paper.

\section{Acknowledgements}

PVR is funded by an IWT scholarship. This work was supported by the projects PRAXIS I and II, as well as by OSTC projects MO/36/003 and MO/36/008 to TB. We thank $H$ Van Paesschen for his help with the illustrations and two anonymous referees for their helpful comments.

\section{References}

Backhuys W (1975). Zoogeography and Taxonomy of the Land $\mathcal{E}$ Fresh-Water molluscs of the Azores. Backhuys \& Meesters: Amsterdam.

Boato A (1988). Microevolution in Solatopupa landsnails (Pulmonata: Chondrinidae): genetic diversity and founder effects. Biol J Linn Soc 34: 327-348.

Cameron RAD, Carter MA (1979). Intra- and interspecific effects of population density on growth and activity in some helicid land snails (Gastropoda: Pulmonata). J Anim Ecol 48: 237-246.

Chiba S (1993). Modern and historical evidence for natural hybridisation between sympatric species in Mandarina (Pulmonata: Camaenidae). Evolution 47: 1539-1556.

Davison A, Clarke B (2000). History or current selection? A molecular analysis of 'area effects' in the land snail Cepaea nemoralis. Proc $R$ Soc Lond B 267: 1-8.

Emerson BC (2002). Evolution on oceanic islands: molecular phylogenetic approaches to understanding pattern and process. Mol Ecol 11: 951-966.

Emerson BC, Oromí P, Hewitt GM (1999). MtDNA phylogeography and recent intra-island diversification among Canary Island Calathus beetles. Mol Phyl Evol 13: 149-158.

Forjaz VH (1997). Alguns vulcões da Ilha de S. Miguel. I Parte. Observatório vulcanológico e geothérmico dos Açores: Ponta Delgada, Açores, Portugal.

Goodfriend GA, Cameron RAD, Cook LM (1994). Fossil evidence of recent human impact on the snail fauna of Madeira. J Biogeogr 21: 309-320.

Goudet J. (1995). FSTAT (version 1.2): a computer program to calculate F-statistics. J Hered 86: 485-486.

Harris H, Hopkinson DA (1976). Handbook of Enzyme Electrophoresis in Human Genetics. Elsevier/North-Holland Publishing Company: Amsterdam.

Hayashi M, Chiba S (2000). Intraspecific diversity of mitochondrial DNA in the land snail Euhadra peliomphala. Biol J Linn Soc 70: 391-401.

Ibrahim KM, Nichols RA, Hewitt GM (1996). Spatial patterns of genetic variation by different forms of dispersal during range expansion. Heredity 77: 282-291.

Johnson MS, Murray J, Clarke B (1993). Evolutionary relationships and extreme genital variation in a closely related group of Partula. Malacologia 35: 43-61.

Johnson MS, Murray J, Clarke B (2000). Parallel evolution in Marquesan partulid land snails. Biol J Linn Soc 68: 577-598.

Jordaens K, Van Dongen S, Van Riel P, Geenen S, Verhagen R, Backeljau T (2002). Multivariate morphometrics of soft body parts in terrestrial slugs: comparison between two data sets, error assessment and taxonomic implications. Biol J Linn Soc 75: 533-542.

Juan C, Emerson BC, Oromí P, Hewitt G (2000). Colonization and diversification: towards a phylogeographic synthesis for the Canary Islands. TREE 15: 104-109.

Leberg PL (1992). Effects of population bottlenecks on genetic diversity as measured by allozyme electrophoresis. Evolution 46: 477-494.

Madec L, Guiller A (1993). Observations on distal genetalia and mating activity in three conchologically distinct forms of the land snail Helix aspersa Müller. J Moll Stud 59: 455-460.

Malhotra A, Thorpe RS (2000). The dynamics of natural selection and vicariance in the Dominican anole: patterns of within-island molecular and morphological divergence. Evolution 54: 245-258.

Medeiros R, Brito C, Frias Martins AM, Jordaens K, Van Riel P, De Wolf $\mathrm{H}$ et al (2000). Conservation genetics of the Azorean endemic slug Plutonia atlantica (Mollusca: Pulmonata). Biol Conserv 93: 77-84.

Mitchell-Thomé RC (1976). Geology of the Middle Atlantic Islands. Beiträge zur regionalen Geologie der Erde. Gebrüder Borntraeger: Berlin. 
Morton B, Britton JC, Frias Martins AM (1998). Coastal Ecology of the Açores. Sociedade Afonso Chaves - Associação de Estudos Açoreanos: Ponta Delgada, Açores, Portugal.

Nei M (1978). Estimation of average heterozygosity and genetic distance from a small number of individuals. Genetics 89: 583-590.

Ochman H, Jones JS, Selander RK (1987). Large scale patterns of genetic differentiation at allozyme loci in the land snails Cepaea nemoralis and Cepaea hortensis. Heredity 58: 127-138.

Raymond M, Rousset F (1995). GENEPOP (version 1.2): population genetics software for exact tests and ecumenicism. J Hered 86: 248-249.

Rice WR (1989). Analyzing tables of statistical tests. Evolution 43: 223-225.

Rohlf FJ (1993). NTSYS-pc version 1.80. Applied Biostatistics Inc.: Setauket, NY.

Schilthuizen M, Lombaerts M (1994). Population structure and levels of gene flow in the Mediterranean land snail Albinaria corrugata (Pulmonata: Clausiliidae). Evolution 48: 577-586.

Selander RK, Kaufman DW (1975). Genetic structure of populations of the brown snail (Helix aspersa). I. Microgeographic variation. Evolution 29: 385-401.
Shimizu J, Ueshima R (2000). Historical biogeography and intraspecific mtDNA introgression in Euhadra peliomphala (the Japanese land snail). Heredity 85: 84-96.

Slatkin M (1985). Rare alleles as indicators of gene flow. Evolution 39: 53-65.

StatSoft Inc. (1995). Statistica for Windows version 5.0. Tulsa: Oklahoma.

Swofford DL, Selander RB (1981). BIOSYS-1: a fortran program for the comprehensive analysis of electrophoretic data in population genetics and systematics. J Hered 72: 281-283.

Thomaz D, Guiller A, Clarke B (1996). Extreme divergence of mitochondrial DNA within species of pulmonate land snails. Proc $R$ Soc Lond B 263: 363-368.

Van Riel P, Jordaens K, Frias Martins AM, Backeljau T (2000). Eradication of exotic species. TREE 15: 515.

Woodruff D (1989). Genetic anomalies associated with Cerion hybrid zones: the origin and maintenance of new electromorphic variants called hybrizymes. Biol J Linn Soc 36: 281294.

Wright S (1978). Evolution and the Genetics of Populations: Volume IV: Variability Within and Among Natural Populations. The University of Chicago Press: London. 